\title{
POSEBAN ASPEKT PRAVA OSOBNOSTI U SPORTU VEZAN UZ ZLOUPORABU DOBI IZBJEGLICA
}

\author{
UDK: $34: 796 / 799$ \\ DOI:10.31141/zrpfs.2020.57.136.305 \\ Izvorni znanstveni rad \\ Primljeno: 20. prosinca 2019.
}

\begin{abstract}
U ovom radu istražili smo pravni aspekt glede prava osobnosti vezan za zlouporabu dobi, u kojemu osoba u statusu izbjeglice neistinito prikaže svoju dob, što u sportskim natjecanjima implicira i neravnopravan položaj u korist izbjeglice. Ako nema dostupnih točnih podataka o dobi sportaša koji se natječe, prihvaća se kao mjerodavna njegova izjava. Istraživanje je dovelo do zaključka da pozitivnopravna regulativa nije odgovarajuća. Ponudili smo jedina dva pravno moguća rješenja, uz krajnji zaključak da je riječ o situaciji u kojoj je pravo nemoćno, pa je potrebno pronaći druga institucionalna rješenja za ove dvojbe, koja bi onda trebalo ugraditi u normativne standarde u sportu.
\end{abstract}

Ključne riječi: javne institucije u sportu, prava osobnosti, šteta, izbjeglice

\section{UVOD}

Gotovo svaka tema može, ali i ne mora biti prikladna za obradu, bilo stručnu, bilo znanstvenu. To zapravo znači da ono što trenutačno „lansira“ neku temu u prvi plan predstavlja cjelokupni kontekst oko te teme. Dakle, treba se nešto dogoditi što nekoj temi ili nekoj skupini tema daje prednost u konkretnoj situaciji i to $\mathrm{u}$ konkurenciji neograničenog broja potencijalnih tema.

Ovaj tekst povod je dobio u medijskoj vijesti prema kojoj je na jednom malonogometnom turniru nastupila i momčad sastavljena (pretežito ili isključivo) od izbjeglica. Ta momčad trebala se natjecati, a natjecanja se, barem načelno i barem radi, ako ne pravde i poštenja, a ono jednakosti pred zakonom, organiziraju među onima koji su približno jednaki ${ }^{1}$ prema kriterijima koji su općeprihvaćeni (npr. u svim sportovima to su kriteriji spola i dobi, u brojnim sportovima ${ }^{2}$ to je kriterij težine, u motociklizmu i automobilizmu obilježja motora, posebno opseg

1 Približno zato što ništa bolje nije moguće. Npr. po kriteriju dobi trebalo bi imati kategorije u kojima se natječu samo oni rođeni istog dana iste godine, a međunarodna praksa kao uobičajeni kriterij ima dvogodišnje razdoblje, slijedom čega su maksimalne dobne razlike gotovo dvije godine, što je kod djece ogromno razdoblje.

2 Npr. boks kao i drugi tzv. borilački sportovi, dizanje utega... 
ili kubikaža) i takva je jednakost podloga za zanimljivost natjecanja, za uporno vježbanje ili treniranje. Poseban i općeprihvaćeni kriterij jest podjela na natjecanja (u prvom redu Olimpijske igre) olimpijaca i paraolimpijaca, ${ }^{3}$ te na izdvojenu skupinu (koja je neka vrsta podvrste paraolimpijaca) gluhih sportaša i sportašica (pri čemu je neobično što, kada već postoje gluhi kao posebna kategorija, zašto ne postoje barem i slijepi u takvom statusu), s više kategorija unutar natjecanja (uglavnom po dobi i spolu, eventualno još po nečemu).

Notorna je činjenica da je jedan od glavnih popratnih problema ${ }^{4}$ kod zbrinjavanja izbjeglica upravo prikupljanje podataka kao što je datum rođenja, glede čega nema objektivnih mogućnosti samostalno precizno nadomjestiti propuštenu informaciju. ${ }^{5}$ Sigurno je da datum rođenja ne spada među najvažnije podatke na svijetu, ali može biti i te kako značajan u mnogim konkretnim situacijama. Ovaj problem ima i svoju posebnu dimenziju kod bavljenja sportom te izaziva posebne pravne implikacije, vezane uz reguliranje posebice odnosa u profesionalnom sportu. Drugim riječima, bilo to zlonamjerno ili ne, moguće je da zbog grešaka glede datuma rođenja dođe do značajnih nejednakosti pred zakonom, a posljedica toga može biti i povreda prava osobnosti jedne ili više osoba, u onome čime se bavi ovaj tekst posebno u sportu. Izbjeglice i migranti nisu najnovija pojava jer su se migracije odvijale kroz čitavu ljudsku povijest. Međutim, u posljednje vrijeme predstavljaju fenomen koji je prilično dramatičan i nije dovoljno reguliran, posebno u svjetlu postojanja različitih shvaćanja država koje su njima obuhvaćene i pogođene, i to u različitim segmentima vezanima uz njihovu integraciju u društvo, uključujući i onu sportsku. Ova sportska integracija posebno je zanimljiva jer se odnosi na organizaciju javnih sportskih natjecanja i na mogućnost da se izbjeglice, kao osobe koje uživaju posebnu pravnu zaštitu države primateljice, u njih aktivno uključe i ravnopravno sudjeluju. Očito je da po ovom pitanju svaka država koja se s njime suočava, sama za sebe ne može postići gotovo ništa, a nesloga među članicama ${ }^{6}$ raznoraznih asocijacija čini ovo pitanje još složenijim i kompleksnijim. Fenomen izbjeglica, kao i drugi, ima svoje brojne aspekte. ${ }^{7} \mathrm{U}$ tom smislu može se ovdje navesti više različitih istraživanja koja su bila vezana uz njihovu integraciju, posebno u lokalnu zajednicu, koja ujedno predstavlja i osnovni integracijski okvir za njihovo uklapanje

3 Osnovna podjela jest podjela sportova na olimpijske i neolimpijske, ali ta podjela bitno gubi na vlastitoj logici i značenju s obzirom na to da su članovi olimpijskih odbora i mnogi savezi neolimpijskih sportova.

4 Naravno, glavni problem je uvijek onaj razlog zbog kojeg je došlo do samog izbjeglištva.

5 Kao što je npr. slučaj s nekim preboljenim bolestima, lomovima kostiju, operacijama i sl.

6 Npr. između Italije i Grčke s jedne strane i Mađarske s druge, a sve su članice EU-a.

7 I ti su aspekti nesumnjivo vrijedni istraživanja jer doprinose boljem razumijevanju uzroka koji dovode do suvremenih migracija, ali pomažu i u kreiranju javnih politika potrebnih za što uspješniju integraciju migranata u društvo. Greške koje su se događale ranije, a bile su uzrokovane stihijskom politikom vezanom uz imigracijske procese, danas služe kao podloga za izradu akcijskih planova kojima je cilj suzbijanje uspostave paralelnih društava što dovodi do problema integracije druge ili treće generacije migranata. O tome više u: Oltmer, Jochen, Migration: Geschichte und Zukunft der Gegenwart, Konrad Theiss Verlag, Darmstadt, 2017. 
u društvo. ${ }^{8}$ Ova istraživanja poslužila su u analizi praktičnih problema s kojima se suočavaju zemlje članice Europske unije, i to posebice tzv. stare Europe, koje ujedno predstavljaju i odredišne zemlje za imigrante, ali ujedno i tzv. zemlje nove Europe, koje su uglavnom tranzitne zemlje, ali su istovremeno izložene pritisku starih država članica da doprinesu smanjivanju imigrantskog pritiska, bilo kroz jaču integraciju migranata putem pripremanja i provođenja različitih javnih integracijskih politika, bilo kroz bolju i kvalitetniju kontrolu zelene granice. ${ }^{9}$

Temeljna hipoteza ovoga teksta jest činjenica da onaj tko kreira pravne norme može puno toga učiniti za stvaranje integracijskog okvira za izbjeglice, kao kategoriju osoba koje uživaju posebnu pravnu zaštitu, ali je potrebno uključiti i druge institucije koje moraju onemogućiti zlouporabu različitih kategorija ljudskih prava, a kao posebna kategorija tih prava jesu i prava osobnosti. ${ }^{10}$ Iako pravo predstavlja vrlo učinkovit alat u provedbi javnih politika, njegov je utjecaj ograničen bez sudjelovanja ostalih dionika u društvu. U tom kontekstu trebalo je istražiti pravni aspekt situacije $\mathrm{u}$ kojoj netko u statusu izbjeglice, zato što neistinito ${ }^{11}$ prikaže svoju dob, dođe u prigodu npr. (bez pravnog temelja) kazneno ne odgovarati za počinjeno kazneno djelo (umjesto odgovarati), sudjelovati u sportskom ili drugom natjecanju $\mathbf{s}$ bitno mlađim osobama koje su zbog toga inferiorne (umjesto biti onemogućen su sudjelovanju) i dr., te time dovede do grube zlouporabe prava osobnosti. ${ }^{12} \mathrm{Mi}$ smo (posebno zbog ograničenosti vremenom i prostorom) odlučili ograničiti istraživanje na zlouporabu dobi, odnosno na činjenicu da nema dostupnih točnih podataka o dobi sportaša koji se natječe, pa se prihvaća kao mjerodavna njegova izjava. Po naravi stvari istraživanje treba dovesti do zaključka je li pozitivnopravna regulativa odgovarajuća i, za slučaj da nije, što bi u njoj, kako i gdje ${ }^{13}$ trebalo promijeniti. Navedeno pretpostavlja uporabu priznatih znanstvenih metoda, od povijesne, preko poredbene pa do induktivne i deduktivne. Dobivene rezultate je, po naravi stvari, moguće iskoristiti i za mnoge druge države, ne ograničavajući se na Republiku

8 O tome je objavljen čitav niz različitih istraživanja koja su se bavila upravljačkim okvirom migrantske krize, te posebice korištenjem institucionalnih kapaciteta za njezino rješavanje. Usp. Gratz, Wolfgang, Das Management der Fluchtlingskrise, NWV Verlag, Wien, 2016.; Speer, Benedikt, »External and Internal Effects of How Austria Has Handlend the Refugee Crisis«, Croatian and Comparative Public Administration, Vol. 18, No 2, 2018., str. 247-268; Kersting, Norbert, »Migration and Integration in German Cities«, Hrvatska i komparativna javna uprava, Vol 18, No 2, 2018., str. 201-222. Od domaćih bi istraživanja valjalo izdvojiti: Koprić, Ivan, Znanstveno-istraživački projekt „,Kapacitet za integraciju migranata“, Institut za javnu upravu, Pravni fakultet Sveučilišta u Zagrebu, Pravni fakultet Sveučilišta u Splitu, 2018.

9 O tome više u: Lopižić, Iva, Lalić Novak, Goranka, »The Role of Deconcentrated State Administration in Migration and Integration Affairs: A Way Forward «, u Koprić, Ivan, Lalić Novak, Goranka, Vukojičić Tomić, Tijana, Migrations, Diversity, Integration, and Public Governance in Europe and Beyond, Institut za Javnu upravu, Zagreb, 2019., str. 289-311.

$10 \mathrm{U}$ tom smislu razmišlja se i na koji način različite društvene institucije trebaju doprinijeti kako bi integracija izbjeglica i migranata u društvenu zajednicu bila što uspješnija. O tome više u: Koprić, Ivan, Lalić Novak, Goranka, Vukojičić Tomić, Tijana, op. cit., str. 25-37.

11 U pravilu će to biti niža dob od stvarne, ali je ipak moguće i obrnuto.

12 Primjera može biti neograničeno, od samostalnog glasovanja jer je netko punoljetan, mogućnosti zatražiti suglasnost za sklapanje braka (jer netko ima 16 godina, a nema 18 godina)...

13 Mislimo posebno na dvojbu je li razmjerno rijetka situacija „vrijedna“ posebne regulative u lex specialis ili treba tražiti drugo rješenje. 
Prof. dr. sc. Mirko Klarić i doc. dr. sc. Blanka Kačer: Poseban aspekt prava osobnosti u sportu vezan uz... Zbornik radova Pravnog fakulteta u Splitu, god. 57, 2/2020, str. 305-319

Hrvatsku. Ono što želimo istaknuti kao pozitivnu stvar i zalog za budućnost jest činjenica da se ova tema dosta temeljito našla i u fokusu HAZU-a, prigodom čega je spomenut i problem zlouporabe dobi. ${ }^{14} \mathrm{U}$ tom kontekstu možemo spomenuti i jednu vrijednu monografiju. ${ }^{15}$

\title{
2. PRAVNA VRELA I DEFINICIJE
}

\author{
Prilično je uobičajeno nabrajanje pravnih vrela (ako tekst uopće sadrži taj dio \\ kao poseban, što nije nužno) započeti od onog najvišeg, dakle od ustava države
}

14 Na okruglom stolu „Položaj migranata u međunarodnom i europskom pravu“, održanom 4. travnja 2019. godine, razmotrena su brojna otvorena pitanja s kojima se susreću hrvatsko društvo i državna uprava kada je riječ o pravnom položaju migranata u Hrvatskoj. Iako Hrvatska nije najtraženija migrantska destinacija u Europskoj uniji, već prije svega ulazna i „prolazna“ država članica, ne manjka primjera u kojima je položaj migranata doveden u pitanje, bilo od strane nekih nadležnih institucija ili u medijima.

Na 51. skupu u sklopu ciklusa Modernizacija prava sudjelovali su: prof. dr. sc. Davorin Lapaš, Pravni fakultet Sveučilišta u Zagrebu, „Migranti i izbjeglice u međunarodnom pravu: sličnosti i razlike“, prof. dr. sc. Vesna Crnić-Grotić, Sveučilište u Rijeci, Pravni fakultet, „Međunarodne obveze Republike Hrvatske glede zaštite ljudskih prava migranata prema praksi Europskog suda za ljudska prava (ESLJP)“, doc. dr. sc. Trpimir Šošić, Pravni fakultet Sveučilišta u Zagrebu, „Dužnost pružanja pomoći na moru u kontekstu migrantskih kretanja morem“, Lora Vidović, pučka pravobraniteljica Republike Hrvatske, „Ostvarivanje prava na azil u Hrvatskoj - pravna jamstva i izazovi provedbe u praksi“, doc. dr. sc. Helga Špadina, Pravni fakultet Sveučilišta J. J. Strossmayera u Osijeku, „Pristup hrvatskom tržištu rada za radnike migrante“ te izv. prof. dr. sc. Ivana Kunda, Sveučilište u Rijeci, Pravni fakultet, „Utjecaj međunarodno privatnopravnih rješenja EU na status migranata“.

Na skupu su pojašnjeni pojmovi migranata i izbjeglica te tražitelja azila, odnosno azilanata, o kojima može ovisiti njihov pravni položaj. Prava tih kategorija osoba uređena su na razinama međunarodnog prava, europskog prava i nacionalnog prava, pa je ključno poznavati relevantne pravne izvore, njihove odnose i tumačenja. O tome je govorio prof. dr. sc. Davorin Lapaš s Pravnog fakulteta Sveučilišta u Zagrebu koji je istaknuo da su prava tih kategorija osoba uređena na razinama međunarodnog prava, europskog prava i nacionalnog prava, zbog čega je ključno poznavati relevantne pravne izvore, njihove odnose i tumačenja.

Prof. dr. sc. Vesna Crnić-Grotić s Pravnog fakulteta Sveučilišta u Rijeci govorila je o međunarodnim obvezama Republike Hrvatske glede zaštite ljudskih prava migranata prema praksi Europskog suda za ljudska prava. Pojasnila je da pravo na azil proizlazi iz Povelje EU-a o temeljnim pravima, pri čemu ne postoji ljudsko pravo ulaska u stranu zemlju, već samo pravo ulaska u svoju zemlju. Vrlo zanimljiv prikaz prava i obveza država koje su dužne pružiti sigurnost migrantima koji se zateknu u moru iznio je dr. Šošić s Pravnog fakulteta u Zagrebu.

Mnoga su pitanja u rasponu od ljudskih prava, prava azila, socijalnih prava, radnih prava, prava iz obiteljskih odnosa, prava na pristup pravosuđu i drugih koja valja analizirati i pritom propitati dostatnost $\mathrm{i}$ primjerenost postojeće regulative i njezine primjene u praksi. Iako su migranti u Hrvatskoj marginalizirana skupina par excellence, pitanja koja se odnose na prava migranata ne bi smjela biti zapostavljena u akademskoj zajednici ni u praktičnom životu. Upravo je pučka pravobraniteljica Republike Hrvatske Lora Vidović govorila o izazovima provedbe prava na azil u praksi i upozorila na primjere nasilja hrvatskih policajaca nad azilantima, kazavši da bi istraga o tim slučajevima trebala biti neovisna o politici. „Mislim da osobe koje nekažnjeno tuku migrante na granici u drugim situacijama tuku navijače na stadionima, ili svoje supruge doma. Radi se o pitanju sigurnosti svih nas i zato je važno da se to istraži“", kazala je Lora Vidović. Na koje sve probleme nailaze izbjeglice prilikom dokazivanja svog statusa, bilo da je riječ o dokazivanju godina, tj. utvrđivanju starosti, dokazivanju braka ili statusa roditelja djece rođene u tijeku migracije ili pak stečenim pravima poput nasljedstva, govorila je izv. prof. Ivana Kunda. U posljednjem dijelu rasprave sudjelovala je dr. sc. Helga Spadina koja je dala prikaz mogućnosti rada za migrante u sklopu hrvatskog tržišta rada. Vidjeti više na: www.hazu.hr.

15 Davorin Lapaš, Međunarodnopravna zaštita izbjeglica, Hrvatski pravni centar, Zagreb, 2008. 
o čijem pravu se radi. Kada se radi o izbjeglicama, onda stvari, ipak, mogu biti nešto drukčije. Izbjeglice su globalni fenomen, a iako je dugo godina izgledalo da je to primarno neeuropski problem, nakon eskaliranja ratnih događanja na sjeveru Afrike, uz nikad miran Bliski istok (Middle Eastern), te uz činjenicu da praktično svi koji odluče otići iz svojih država kao destinaciju na kojoj ih navodno čeka bolji život odabiru Europu, točnije njezin razvijeni dio - stvari su se bitno promijenile. Uslijed navedenoga jasno je da je donesen velik broj međunarodnih akata koji se bave izbjeglicama. Tako možemo navesti Konvenciju o položaju izbjeglica (Convention relating to the Status of Refugees) iz 1951. god. ${ }^{16}$ i Protokol koji se odnosi na položaj izbjeglica (Protocol relating to the Status of Refugees) iz 1967. god. ${ }^{17}$ Slijedili su regionalni ${ }^{18}$ (misli se na regije svijeta) akti: za Afriku Konvencija o izbjeglicama (OAU Convetion on Refugees) iz 1969. god., za Latinsku Ameriku - Kartagenska deklaracija (Cartagena Declaration) iz 1984. god., za EU Zajednički europski azilantski sustav (the Common European Asylum System) iz 2005. god. Inače, međunarodni ugovori koji su sklopljeni, potvrđeni i objavljeni u skladu s Ustavom Republike Hrvatske, ${ }^{19}$ a koji su na snazi, čine dio unutarnjega pravnog poretka Republike Hrvatske, te su po pravnoj snazi iznad zakona. Njihove se odredbe mogu mijenjati ili ukidati samo uz uvjete i na način koji su u njima utvrđeni, ili suglasno općim pravilima međunarodnog prava (Ustav, čl. 140.).

S obzirom na to da je Republika Hrvatska zemlja punopravna članica EU-a (od 1. srpnja 2013. god.), pravna vrela su i različiti europski pravni akti koji se odnose na ovu materiju, a čine ono što se obično naziva europska pravna stečevina ili acquis communautaire.

Osim navedenih međunarodnih vrela, ključno značenje ima Ustav Republike Hrvatske, koji sadrži čitav niz iznimno važnih odredbi za ljudska prava uopće, a posebno se na pitanje izbjeglica odnosi članak 33. st. 1. prema kojemu strani državljani i osobe bez državljanstva mogu dobiti utočište u Republici Hrvatskoj, osim ako su progonjeni za nepolitičke zločine i djelatnosti oprečne temeljnim načelima međunarodnog prava.

Zakon koji ima ulogu lex specialis jest Zakon o statusu prognanika i izbjeglica, ${ }^{20}$ a kako se u ovom tekstu bavimo pravima osobnosti u sportu, status pravnog vrela

16 Vidjeti na http://www.unhcr.org/protect/PROTECTION/3b66c2aa10.pdf/

17 Đuro Degan, Vladimir, Međunarodno pravo, drugo osuvremenjeno izdanje, Pravni fakultet Sveučilišta u Rijeci, Rijeka, 2006., str. 508.; Ortakovski, Vladimir, „Refugee Crisis in Europe and International Law", u: From an Individual to the European Integration - Discussion on the Future of Europe, Lieber Amicorum in Honour of Silvo Devetak, Maribor, 2019., str. 365.

18 Misli se na regije svijeta i to ili kontinente ili značajne njihove dijelove.

19 Ustav Republike Hrvatske, NN 56/90, 135/97, 8/98 - pročišćeni tekst, 113/00, 124/00 - pročišćeni tekst, 28/01, 41/01 - pročišćeni tekst, 55/01, 76/10, 85/10 - pročišćeni tekst, 05/14 - Odluka Ustavnog suda broj: SuP-O-1/2014. od 14. siječnja 2014., kojom je čl. 62. Ustava nadopunjen st. 2. - dalje: Ustav ili Ustav RH.

20 Zakon o statusu prognanika i izbjeglica, NN 96/93, 39/95, 29/99, 128/99, 50/00, 86/02, 51/13, 98/19 - u daljnjem tekstu: Zakon ili Zakon o statusu prognanika i izbjeglica. 
svakako imaju i Zakon o obveznim odnosima ${ }^{21}$ (koji je sedes materiae glede odgovornosti za povredu prava osobnosti i odštetnu odgovornost uopće) i Zakon o sportu, ${ }^{22}$ kao i bilo koji drugi zakon i podzakonski akt koji se bavi, manje ili više, ovom problematikom.

Sudska praksa i pravna znanost značajno su neizravno (sui generis) ${ }^{23}$ vrelo prava. Sudska praksa djeluje snagom argumenta i argumentom snage, a pravna znanost djeluje snagom argumenta, što je osobito značajno u situaciji kada sudske prakse još nema, a pravna je regulacija loša, ili je uopće nema.

Radi lakšeg korištenja teksta, preglednosti i potpunosti, a i iz razloga što se često dva dva pojma potpuno neopravdano tretiraju kao sinonimi, slijede definicije ključnih pojmova: izbjeglica i prognanik.

Glede pojmova prognanik i izbjeglica najbolje je uputiti na zakonske definicije, unatoč tome što se baš u tome što su sadržaj istog zakona krije razlog čestog identificiranja, kao da su sinonimi ili jednoznačnice. U članku 2. Zakona propisano je kako slijedi:

Osobi koja je s ratom ugroženog područja na teritoriju Republike Hrvatske, samostalno ili organizirano putem općinskog štaba civilne zaštite, Hrvatskog Crvenog križa, centra za socijalni rad i dr., a na osnovi procjene organa Ministarstva unutarnjih poslova ili nadležnog zapovjedništva Hrvatske vojske, napustila mjesto prebivališta da bi izbjegla neposrednu opasnost za život pred agresijom i drugim oružanim akcijama, priznaje se status prognanika ili izbjeglice. Prognanik u smislu ovoga Zakona je osoba iz stavka 1. ovoga članka koja je s jednog područja Republike Hrvatske izbjegla na drugo područje Republike Hrvatske. Izbjeglica u smislu ovoga Zakona je osoba iz stavka l. ovoga članka koja je iz Republike Hrvatske izbjegla u inozemstvo. Ratom ugroženo područje proglašava Vlada Republike Hrvatske.

Potrebno je naglasiti da naprijed navedeno zakonsko rješenje $s$ jedne strane objašnjava (kako smo naveli pogrešno) izjednačavanje pojmova prognanik i izbjeglica jer tada izbjeglice u današnjem smislu gotovo da i nije bilo, a postojao je ogroman broj osoba koje su protjerane iz svojih domova uslijed agresije na Republiku Hrvatsku, a s druge strane upućuje (neizravno, propustom) na međunarodne akte glede tih istih pojmova kada se radi o dolasku osoba iz inozemstva. Republika Hrvatska osigurava, ovisno o materijalnim mogućnostima, ali i o domaćim i međunarodnim vrelima, odgovarajuću potporu. Potpora može biti nužni smještaj, prehrana, školovanje djece, stalna novčana pomoć, zdravstvena zaštitu i pomoć za podmirenje drugih nužnih životnih potreba svim osobama kojima se na osnovi ovoga Zakona prizna status prognanika ili izbjeglice, sve ovisno o mogućnostima i potrebama. Potrebno je spomenuti da na stvorenu konfuziju glede nazivlja

${ }^{21}$ Zakon o sportu, NN 71/06, 124/10, 124/11, 86/12, 94/13, 85/15, 19/16 - ispravak, 98/19 - u daljnjem tekstu: ZOS ili Zakon o sportu.

22 Zakon o obveznim odnosima, NN 35/05, 41/08, 125/11, 78/15, 29/18 - u daljnjem tekstu: Zakon o obveznim odnosima ili ZOO.

23 Vidjeti više o tome, uz uporabu pojma neizravan pravni izvor, u: Klarić, Petar, Vedriš, Martin, Građansko pravo, Narodne novine, Zagreb, 2008., str. 23. 
nije pozitivno djelovalo ni to što i danas postoji Vladin ured s nazivom Ured za prognanike i izbjeglice.

Nešto kasnije od Zakona o statusu prognanika i izbjeglica donesen je Zakon o azilu $^{24}$ koji sadrži definiciju prema kojoj je izbjeglica stranac koji se ne nalazi u zemlji svog državljanstva te se zbog osnovanog straha od proganjanja zbog svoje rase, vjere, nacionalnosti, pripadnosti određenoj društvenoj skupini ili političkog mišljenja, ne može ili se zbog tog straha ne želi staviti pod zaštitu te zemlje, odnosno osoba bez državljanstva koja se nalazi izvan zemlje uobičajenog boravišta, a koja se ne može ili se zbog osnovanog straha ne želi vratiti u tu zemlju. Ovo dovodi do potrebe za rješenjem kolizije ili antinomije ${ }^{25} \mathrm{i}$ to je razmjerno jednostavno. Jasno je da je Zakon o azilu ${ }^{26}$ glede ove stvari lex specialis i po tome ima prednost. ${ }^{27}$

Prema naprijed navedenim međunarodnim ugovorima, izbjeglice su osobe koje bježe od oružanog sukoba ili proganjanja. Vanjska je manifestacija odlazak iz svojeg doma, najčešće u velikoj žurbi i s jako malo ili nimalo stvari, često i bez osobnih dokumenata ili (što se nažalost često događa) s tuđim osobnim ispravama. Migranti su, međutim, nešto drugo. Oni su odabrali napustiti svoju zemlju i to ne zbog posredne ili neposredne opasnosti po imovinu ili život i zdravlje (progon ili smrt sebe i/ili bliske osobe), nego radi boljeg života. Za razliku od izbjeglica koji se ne mogu sigurno vratiti kući, migranti se ne suočavaju s takvim preprekama. Ova razlika iznimno je važna za sve vlade i to zato što se države bave migrantima $i$ izbjeglicama kao različitim kategorijama. I to kako prema domaćim propisima, tako i po međunarodnom pravu. Države imaju posebnu odgovornost prema svakome tko traži azil na njihovu teritoriju ili na njihovim granicama. UNHCR (United Nations High Commissioner for Refugees) utemeljen je 1950. u svezi sa stanjem nakon Drugog svjetskog rata i kao međunarodna organizacija pomaže zemljama u ispunjavanju njihovih obaveza vezanih za azil i zaštitu izbjeglica.

Vjerujemo da su i mediji dali svoj doprinos nepreciznoj uporabi pojmova prognanik i izbjeglica, rabeći ih prečesto kao da se radi o sinonimima, što neprijeporno nisu. U tom kontekstu ipak treba spomenuti i jedan stav koji mnogi pripisuju baš UNHCR-u u svezi s upitom što su milijuni osoba koje legalno prelaze državne granice i izlažu svoj život i zdravlje i život i zdravlje obitelji - što su oni? Izbjeglice ili migranti? Ustvari, čini se da su i jedno i drugo. Većina je ljudi koji su ove godine došli naročito u Italiju i Grčku, iz zemalja koje su zahvaćene ratom ili iz zemalja za koje se smatra da „proizvode izbjeglice“ iz nekog drugog razloga, i njima je neophodna međunarodna zaštita. Međutim, manji broj dolazi iz drugih država i za mnoge od njih bilo bi ispravno upotrijebiti riječ „migrant“. Dakle, u UNHCR-u kažemo , izbjeglice“ $i$,,migranti “ kada govorimo o kretanjima ljudi preko mora ili

24 Zakonu o azilu, NN 79/07, 88/10, 143/13 - u daljnjem tekstu: ZOA ili Zakon o azilu.

25 Vidjeti tako i više u: Bobbio, Norberto, Eseji iz teorije prava, Logos, Split, 1988., str. 123-135.

${ }_{26}$ Treba dodati da taj zakon spada u skupinu onih kod kojih se na početku navodi određeni broj definicija za potrebe tog zakona, što smatramo doprinosom pravnoj sigurnosti. Tu se nalazi i zakonska definicija pojma izbjeglica.

$27 \mathrm{~S}$ obzirom na to da se radi o preuzimanju definicije iz međunarodnih ugovora koji imaju veću pravnu snagu od zakona, ovo i nije toliko bitno. 
u nekim drugim okolnostima, za koje mislimo da uključuju obje skupine - kretanja u plovilima u jugoistočnoj Aziji još su jedan primjer. Kažemo „izbjeglice“ kada mislimo na ljude koji bježe od rata ili proganjanja preko međunarodne granice. A kažemo „migranti“ kada mislimo na ljude koji se kreću iz razloga koji nisu obuhvaćeni pravnom definicijom izbjeglice.

\section{POSTAVLJANJE I ANALIZA PROBLEMA}

U ovom dijelu teksta, na određeni način uvodnom dijelu, odlučili smo unijeti osnovno o pravu osobnosti, da bismo nakon toga temeljito istražili povredu prava osobnosti u svezi sa zlouporabom dobi u sportu. Zato smo smatrali korisnim, u kratkim crtama, navesti osnovno o pravu osobnosti, te nakon toga prijeći na primjenu na konkretnom (i realnom, mada hipotetičnom) primjeru.

\subsection{PRAVO OSOBNOSTI}

Pravo osobnosti još je uvijek nedovoljno definiran pojam i njegovo shvaćanje razlikuje se od države do države. Za bolje razumijevanje tog prava bitno je poznavati neke od njegovih temeljnih osobina po kojima se razlikuje od drugih vrsta prava. ${ }^{28}$ Pravo osobnosti je, prije svega, apsolutno pravo koje djeluje erga omnes. Treba imati na umu i to da pravo osobnosti nije urođeno pravo i iz toga razloga treba izbjegavati klasični prirodnopravni pristup..$^{29}$ Nadalje, treba voditi računa o tome promatra li se pravo osobnosti kao norma objektivnog prava ili govorimo o subjektivnom pravu ličnosti određenog pravnog subjekta. ${ }^{30}$ Slijedom navedenoga, prenosimo definicije prof. dr. sc. Alda Radolovića, koji pravo osobnosti definira u subjektivnom i objektivnom smislu: prava osobnosti u objektivnom smislu predstavljaju skup normi etičko-pravnog poretka kojima se regulira pravo svakog pravnog subjekta na ispoljavanje i razvoj vlastite ličnosti u skladu sa stupnjem psihosocijalnog razvoja, a u subjektivnom smislu je pravo određenog pravnog subjekta da od svih drugih pravnih subjekata traži i ostvaruje poštovanje i razvoj vlastite ličnosti u skladu sa svojim psihosocijalnim stupnjem razvoja. ${ }^{31}$

Budući da u hrvatskom zakonodavstvu nemamo čvrste teorijske temelje, teško je govoriti o nekom ustaljenom nazivu. ${ }^{32}$ Osobnost se u njemačkoj pravnoj terminologiji naziva Persönlichkeitsrecht, u talijanskoj diritti della personalita, a u engleskom jeziku personality rights. Nazivi "die Person", "la persona", "person" bili bi odraz nečeg novog i drugačijeg od onog što u tim istim jezičnim područjima znači

28 Dropulić, Julijano, Pravo na privatni život i duševni integritet, Vizura, Zagreb, 2002., str. 40-41.

29 Ibid., str. 114.

30 Ibid.

31 Radolović, Aldo, »Pravo osobnosti u novom Zakonu o obveznim odnosima«, Zbornik Pravnog fakulteta Sveučilišta u Rijeci, Vol. 27. No. 1., Rijeka, 2006., str. 133.

32 Gavella, Nikola, Osobna prava I. dio, Pravni fakultet Sveučilišta u Zagrebu, 2000., Zagreb, str. 27. 
riječ "osoba" ${ }^{33}$ Kad bismo doslovno prevodili, onda bi to bilo osobnost, identitet, ličnost i sl. ${ }^{34}$ Naziv osobna prava trpi opravdane prigovore jer osobna prava postoje i u imovinskom dijelu građanskog prava kao što su pravo plodouživanja, pravo uzdržavanja i sl. ${ }^{35}$ Naziv pravo ličnosti koriste jugoslavenski autori, međutim taj naziv nije upotrebljiv iz više razloga. Prije svega, ako ga promatramo s lingvističke strane, sam izraz lična prava ima u vidu prava gdje se pojam ličnosti transformira iz imenice u pridjev te se takva lična prava uobičajeno suprotstavljaju onim pravima koja slobodno kolaju u pravnom poretku. ${ }^{36}$ Naziv pravo osobnosti u duhu je hrvatskog jezika i korisnicima je najprihvatljiviji. ${ }^{37}$ Koristi ga ZOO te ga, poštujući zakonsku terminologiju, koristimo i mi.

Potrebno je naglasiti (posebno kako bi se izbjegla dvojba i povezivanje s bivšom državom i bivšim sustavom) da povreda prava osobnosti sadržajno nije uvedena u hrvatski pravni sustav tek 1. siječnja 2006. god. kao danom stupanja na snagu Zakona o obveznim odnosima. Naime, tada je (pored ostaloga) došlo do promjene terminologije i nematerijalna šteta postala je neimovinska šteta. ${ }^{38}$ Međutim, sadržajno su prava osobnosti postojala još i u bivšoj državi, a bez prekida to je nastavljeno putem primjene pravnih pravila i nakon osamostaljenja Republike Hrvatske, sve do stupanja na snagu Zakona o obveznim odnosima. ${ }^{39}$ Iznimno je značajno i pozitivno što se hrvatski zakonodavac odlučio za vrlo elastičnu zakonsku definiciju, koja ne zahtijeva u kratkom roku bilo kakvu promjenu u zakonskom tekstu, neovisno o tome što se u međuvremenu dogodi, jer definicija „pokriva“ široko područje. Prema Zakonu o obveznim odnosima (čl. 19.) pod pravima osobnosti razumijevaju se prava na život, tjelesno i duševno zdravlje, ugled, čast, dostojanstvo, ime, privatnost osobnog i obiteljskog života, sloboda i dr., a pravna osoba ima sva navedena prava osobnosti, osim onih vezanih uz biološku bit fizičke osobe, a osobito pravo na ugled i dobar glas, čast, ime, odnosno tvrtku, poslovnu tajnu, slobodu privređivanja i dr. Ne radi se o taksativnom nabrajanju, nego onom exempli causa. Pri tome je više nego jasno, barem glede stanja u Republici Hrvatskoj, da je svaki čovjek pri sudjelovanju u bilo kojem obliku natjecanja (a natjecanja su bitan dio sporta, čak i u rekreaciji) objektivno ugrožen u svojim pravima osobnosti, barem ako pri tome mislimo na duševno zdravlje, ugled i dobar glas, dostojanstvo, privatnost osobnog i obiteljskog života.

33 Radolović, Aldo, Pravo ličnosti kao kategorija građanskog prava, doktorska disertacija obranjena na Pravnom fakultetu Sveučilišta u Zagrebu, Zagreb 1985., str. 115.

34 Brezak, Milan, Pravo na osobnost, Pravna zaštita osobnih podataka od zlouporabe, Nakladni zavod Matice hrvatske, 1998., Zagreb, str. 13.

35 Radolović, Aldo, Pravo osobnosti u novom Zakonu o obveznim odnosima, op. cit., str. 148.

36 Radolović, Aldo, Pravo ličnosti kao kategorija građanskog prava, op. cit., str. 114.

37 Dropulić, Julijano, Pravo na privatni život i duševni integritet, op. cit., str. 19.

38 Vidjeti više u: Gorenc, Vilim, Belanić, Loris, Momčinović, Hrvoje, Perkušić, Ante, Pešutić, Andrea, Slakoper, Zvonimir, Vukelić, Mario, Vukmir Branko, Komentar Zakona o obveznim odnosima, Narodne novine, 2014. Također više u: Kačer, Hrvoje, Radolović, Aldo, Slakoper, Zvonimir, Zakon o obveznim odnosima s komentarom, Poslovni zbornik, Zagreb, 2006.

39 Gavella, Nikola, op. cit., str. 23-25, Vidjeti i: Radolović, Aldo, Pravo ličnosti kao kategorija građanskog prava, op. cit. 
ZOO je u definiranju prava osobnosti bio vrlo širok i elastičan, širom otvarajući vrata širenju liste onoga što spada pod pravo osobnosti. Zato smatramo i kako je zasigurno u pravu prof. Nikola Gavella (kao jedan od najvećih autoriteta hrvatske pravne znanosti uopće) kada je prigodom nabrajanja vrsta osobnih prava postupio tako da je nabrojio njih 6 (1. pravo na tjelesni integritet, 2. pravo na slobodu, 3 . pravo na čast i ugled, 4. pravo na privatnost, 5. pravo na osobni identitet, 6. pravo na duševni integritet), ali je uveo i sedmo, jako općenito, pod nazivom: pravo na zaštitu ostalih neimovinskih osobnih dobara. ${ }^{40}$

\subsection{POVREDA ZLOUPORABOM DOBI U SPORTU}

\subsection{1. ČINJENIČNO STANJE}

U svrhu istraživanja kojim se bavi ovaj tekst potrebno je zamisliti natjecanje u bilo kojem sportu koji uključuje dobnu granicu, neovisno o tome radi li se na primjer o tenisu, atletici, plivanju ili nekom drugom. Pri tome dosta značajno može biti da se ne radi o natjecanju koje kombinira dob s nekim drugim kriterijem, težinom, zato što bi to moglo na neki način usložiti situaciju i izvedene zaključke moguće relativizirati. Možda je upravo iz navedenih razloga za hipotetični primjer idealan tenis (globalno jedan od najpopularnjih sportova, ali i jedan od najuređenijih u smislu postojanja preciznih pravila) kao sport u kojem se organiziraju natjecanja odvojeno za muškarce i žene, te posebno za dobne skupine do $12,{ }^{41}$ do 14 , do 16 , do 18 i preko 18 godina. Poznato je kako je upravo u najnižim dobnim skupinama relativno česta velika, čak i vizualno potpuno jasna razlika između djece koja se natječu. $\mathrm{U}$ tom smislu nisu rijetkost fotografije s natjecanja npr. do $12 \mathrm{i}$ do 14 godina na kojima se vide dva dječaka ili dvije djevojčice od kojih je jedan (jedna) otprilike barem dvostruko teži, odnosno teža i viši ili viša za $30-40$, pa i više centimetara. Potpuno je jasno, po svim relevantnim istraživanjima da, čak i kada bi mentalna zrelost te djece bila jednaka (a nije kod različite dobi), već bitno različite fizičke predispozicije čine natjecanje lišenim elementa neizvjesnosti (naravno, pri tome ne uključujemo druge moguće kriterije i svojstva kao što su pretjerana pretilost, sporost, nekoordiniranost pokreta itd., nego ih smatramo načelno neutralnim). Ako se na natjecanje prijavi izbjeglica i prethodno provede uobičajeni postupak registracije, nastaje situacija da će biti uredno sportski registriran za određeni klub i da će tamo biti upisan čitav niz podataka (uključujući zdravstveni iskaz ovlaštenog liječnika sportske medicine ili medicine rada) da je zdravstveno sposoban/na za bavljenje konkretnim sportom. Ogromna većina podataka pri tome je potpuno objektivna, potpuno istinita i lako provjerljiva, od visine, preko težine pa dalje. Međutim pravi prostor mogućih problema, pa i zlouporaba, „leži“ na području koje je na primjeru izbjeglica često vrlo teško provjerljivo, ponekad i nemoguće -

40 Gavella, Nikola, op. cit., str. 30.

41 Na razini koja nije međunarodna i po donekle drukčijim pravilima u Republici Hrvatskoj postoje i natjecanja do 8 i do 10 godina. 
ime i prezime, podaci o roditeljima, državljanstvo i, svakako, datum rođenja odnosno dob. Točno je pri tome da mnogi izbjeglice sa sobom imaju vlastite isprave kao javne isprave koje daju vjerodostojne podatke, pored ostalog i o tome kada su rođeni. Međutim, notorno je da uslijed niza razloga (od onih objektivnih pa do subjektivnih, od onih koji su motivirani samo time da se lakše eventualno dobije azil, pa sve do toga da je motivacija baš u zlouporabi na temelju tih podataka, pa i dobi) postoje izbjeglice koji ili nemaju nikakve dokumente ili pak zlorabe one tuđe. Cinjenica je da su državna tijela u takvoj situaciji, barem u prvom trenutku, u vrlo teškom položaju. Naime, današnji stupanj razvitka medicinske znanosti ne raspolaže preciznim instrumentarijem koji bi dokazao nečiju dob s preciznošću koja je za natjecanja u sportu potrebna (tu se često radi o mjesecima ili o godini, dvije ili tri razlike koje bi bilo dobro utvrditi, a to nije moguće). Poznato je tako, na primjer, da se u medicini snimanjem kostiju ruke - šake - može utvrditi tzv. koštanu starost, ali nije poznato da bi bilo prihvaćeno da se na taj način službeno utvrđuje starost nečijeg djeteta (pored ostalog zato jer je jasno da mnoga djeca koja fizički u određenoj mjeri zaostaju u svojem razvitku imaju tu koštanu starost na razini godinu, dvije ili tri manje od svoje stvarne dobi). Navedeno zapravo znači da će se izbjeglici, odnosno roditeljima, na neki način povjerovati na riječ i da će se kao relevantan podatak uzeti datum koji oni navedu kao dan rođenja njihova djeteta. Bitno je uočiti da u današnje vrijeme nevjerojatnog tehnološkog razvitka dostupnog i izbjeglicama bilo koja vijest, bilo koje saznanje o tome da je negdje netko uspio nešto ostvariti kao izbjeglica u nekoj državi u kratkom roku dopire do mnogih drugih u sličnom položaju. Tako je na primjer vijest o tome da povoljan tretman imaju izbjeglice iz Sirije dovela do toga, za vrijeme nedavnog rata u Siriji, da se ogroman broj izbjeglica deklarirao kao da su iz Sirije, iako su stvarno bili iz neke druge države o kojima se slabije „,vodilo računa“ (jer nije bilo rata ili su strahote rata bile po globalnoj percepciji događanja blaže i sl.). Opće je poznato da djeca uživaju veću zaštitu nego odrasli i to je stvarno jak motiv za prikazivanje što niže dobi, bilo za sebe ili za nekog svojeg.

Naravno da je za kriterij državljanstva osobe koja nema nikakvih isprava moguće, barem u prvom trenutku, koristiti i znanje jezika kojim se najviše koriste državljani te države. Međutim, treba prihvatiti i činjenicu da je jako teško raspolagati potrebnim brojem prevoditelja za sve moguće jezike o kojima se u takvim situacijama može raditi, a točno je da i po pitanju jezika u brojnim državama (posebno velikima) postoje velike razlike. Točnije, ne smijemo zaboraviti da postoje države u kojima su aktualne ne samo ratne strahote, nego se radi i o ukupnom stupnju razvitka koji je u bitnom obilježen i tzv. plemenskim uređenjem i nepismenošću i općenito izostankom javnih registara u koje se upisuju podaci na razini i u mjeri koje gotovo u svim državama svijeta, barem donekle razvijenima, predstavljaju standard o kojem se niti ne raspravlja. Teško je uspoređivati stupanj osobnih podataka kojima raspolažu državna tijela u razvijenim državama s onima nerazvijenima. Čak i u razvijenim državama, odnosno među njima, postoje razlike po pitanju npr. otisaka prstiju i sl. (na primjer otisak prstiju je nešto što objektivno olakšava otkrivanje identiteta osobe, a onda i njezinih osobnih podataka). Još daleko pouzdanije nego 
otisci prstiju služe DNK-podaci, a za jedno i drugo treba naglasiti da potencijalni dodatni problemi nastaju baš prigodom (pokušaja) uzimanja otiska ili potrebnog „materijala“ za DNK. Upravo je aktualna migrantska kriza na istočnim granicama RH pokazala kako izbjeglice uglavnom izbjegavaju navedeni tip identifikacije, jer vrlo dobro znaju da im to ili onemogućava ili barem otežava manipuliranje pravima što ih međunarodna zajednica priznaje izbjeglicama.

Vraćajući se na naš hipotetični primjer, imamo 32 dječaka koji se natječu na teniskom turniru i za osvajanje titule pobjednika potrebno je ostvariti 5 pobjeda. Dakle, natječe se 31 dijete sa svim potrebnim službenim podacima, pa i onim o svojoj dobi, i jedno dijete - izbjeglica koje je samo izjavilo da ima 12 godina. Naravno da netko može izraziti čuđenje kako se netko tko nema ni za hranu, ni za piće, može baviti sportom, ali trend je pomoći izbjeglicama u što boljoj integraciji, a to onda znači i bavljenje sportom, a kada se jednom (tamo na početku, kod prve evidencije) dade pogrešan podatak, onda se on prirodno ,nastavlja“ dalje, praktično do smrti te osobe. Istodobno, u tim je niskim dobnim kategorijama količina treninga kod bilo koga objektivno mala, što olakšava „nadoknađivanje“, posebno onima starijima. Navedeni dječak izbjeglica u stvarnosti ima mentalne sposobnosti koje odgovaraju njegovoj dobi, jednako ili slično kao i one fizičke sposobnosti, a stvarno zamislimo da ima $\mathbf{1 5}$ godina. Potpuno je sigurno da će taj dječak, u potpuno neravnopravnom natjecanju, poraziti sve one druge i tako onome kojega pobijedi u finalu uskratiti prvo mjesto, onome kojega pobijedi u polufinalu uskratiti sudjelovanje u finalu i tako redom.

\subsubsection{PRAVNA ANALIZA}

$\mathrm{Na}$ temelju lokalnih natjecanja stvaraju se određene rang-liste, ali i stječe pravo sudjelovanja na međunarodnim natjecanjima. Zato ovakav hipotetični, ali vrlo realan slučaj smatramo iznimno značajnim i za domaće i za međunarodno pravo, a niti jedna pravna norma nije uredila ovakvu situaciju, barem ne na način da nam pruži odgovarajuće rješenje. Zapravo dva ekstremna rješenja jesu: a) uopće ne dopustiti natjecanje izbjeglicama ili b) potpuno povjerovati u podatke koje oni daju, ukoliko ne postoje drugi vjerodostojni koji ih negiraju.

U praksi, bojimo se, prevladat će ova druga opcija, osim ako bi se dogodilo da netko stvarno pretjera, pa da tako npr. imamo izbjeglicu koji se brije i istodobno tvrdi da ima 12 godina.

Naprijed navedeno stvarno znači da je vrlo izgledna situacija (koja stvarno ovisi samo o tome hoće li neki izbjeglica odlučiti ili neće odlučiti zlorabiti svoju $\mathrm{dob}^{42}$ na ovaj način) u kojoj dijete izbjeglica nastupa na sportskom natjecanju na kojemu ne bi smio nastupiti i pri tome krši sva moguća prava, od prava na jednakost pa dalje, a pravo je, barem de lege lata, nemoćno. Stvarno to znači da će npr. svi znati da je to tako, da su prava svim sudionicima povrijeđena, uključujući tu svakako i pravo osobnosti (makar ono sedmo, po kriterijima Nikole Gavelle koje smo citirali

${ }^{42}$ Zapravo zlorabiti nepostojanje službenih evidencija i dokumenata o svojoj dobi. 
u ovom tekstu), a bez mogućnosti dokazati najprije neistinitost tvrdnje o dobi, pa posljedično i o (ne)legalnosti nastupa.

Ovako kako smo naveli izgleda da će i ostati dok znanost (medicina) ne omogući sprečavanje takvih zlouporaba. Alternativa je jedino (za sada) ponavljanje slučaja Lancea Armstronga, ${ }^{43}$ dakle priznanje samog izbjeglice, vjerojatno daleko nakon dovršetka samog natjecanja ili čak i općenito bavljenja sportom. Pravno, tada će bilo koji zahtjev biti očito u zastari, a da kojim slučajem nije tako, onda bi se mogli provesti bezbrojni postupci zbog povrede prava osobnosti (što naravno ne isključuje ni imovinsku štetu), a o tzv. autonomnom sportskom pravu ili unutarnjem sportskom pravu ovisit će hoće li se i kako poništiti svi sportski rezultati.

\section{ZAKLJUČAK}

Sigurni smo da je osnovna hipoteza ovog rada i te kako dokazana istraživanjem. Naime, više je nego jasno da problem zlouporabe dobi u sportu od strane izbjeglica pravno nije moguće učinkovito (a to znači kvalitetno i brzo) riješiti, osim već $a$ priori neprihvatljivim rješenjem koje se svodi na to da se izbjeglicama zabrani bavljenje sportom (barem u dijelu natjecanja). Jasno je da bi takva zabrana (da do nje dođe) bila pravno nasilje sui generis kojim bi se moguće kršilo čitav niz prava izbjeglica, pored ostaloga i pravo na integraciju u konkretno okruženje. Pri zaključivanju što raditi, treba se sjetiti i Domovinskog rata i bezbrojnih (naših) prognanika i izbjeglica i ogromne zahvalnosti svakome tko im je ikada i na bilo koji način pomogao. Možda je rješenje i priznati nemoć prava (za sada, ali posebno zbog nemoći medicine) i prihvatiti da je bolje trpjeti jednu ili nekoliko zlouporaba, nego spriječiti čitavu društvenu skupinu da se natječe u sportu.

\section{LITERATURA}

1. Bobbio, Norberto, Eseji iz teorije prava, Logos, Split, 1988.

2. Brezak, Milan, Pravo na osobnost, Pravna zaštita osobnih podataka od zlouporabe, Nakladni zavod Matice hrvatske, Zagreb, 1998.

3. Degan, Vladimir Đuro, Međunarodno pravo, drugo osuvremenjeno izdanje, Pravni fakultet Sveučilišta u Rijeci, Rijeka, 2006.

4. Dropulić, Julijano, Pravo na privatni život i duševni integritet, Vizura, Zagreb, 2002.

5. Gavella, Nikola, Osobna prava I. dio, Pravni fakultet Sveučilišta u Zagrebu, 2000., Zagreb.

6. Gratz, Wolfgang, Das Management der Fluchtlingskrise, NWV Verlag, Wien, 2016.

43 Najpoznatiji biciklist svih vremena, najprije po nevjerojatnim i neponovljivim sportskim rezultatima, zatim i po priznanju koje je dao in vivo prigodom intervjua koji je s njim radila Oprah Whitney. 
7. Gorenc, Vilim, Belanić, Loris, Momčinović, Hrvoje, Perkušić, Ante, Pešutić, Andrea, Slakoper, Zvonimir, Vukelić, Mario, Vukmir Branko, Komentar Zakona o obveznim odnosima, Narodne novine, 2014.

8. Kačer, Hrvoje, Radolović, Aldo, Slakoper, Zvonimir, Zakon o obveznim odnosima s komentarom, Poslovni zbornik, Zagreb, 2006.

9. Kersting, Norbert, »Migration and Integration in German Cities«, Hrvatska $i$ komparativna javna uprava, Vol 18, No 2, 2018.

10. Klarić, Petar, Vedriš, Martin, Građansko pravo, Narodne novine, Zagreb, 2008.

11. Koprić, Ivan, Lalić Novak, Goranka, Vukojičić Tomić, Tijana, „Migrations, Diversity, Integration and Public Governance in Europe and Beyond“, u Koprić, Ivan, Lalić Novak, Goranka, Vukojičić Tomić, Tijana (ur.): Migrations, Diversity, Integration and Public Governance in Europe and Beyond, Institut za javnu upravu, Zagreb, 2019.

12. Koprić, Ivan, Znanstveno-istraživački projekt „Kapacitet za integraciju migranata“, Institut za javnu upravu, Pravni fakultet Sveučilišta u Zagrebu, Pravni fakultet Sveučilišta u Splitu, 2018.

13. Lapaš, Davorin, Međunarodnopravna zaštita izbjeglica, Hrvatski pravni centar, Zagreb, 2008.

14. Lopižić, Iva, Lalić Novak, Goranka, ,,The Role of Deconcentrated State Administration in Migration and Integration Affairs: A Way Forward“", u Koprić, Ivan, Lalić Novak, Goranka, Vukojičić Tomić, Tijana, Migrations, Diversity, Integration, and Public Governance in Europe and Beyond, Institut za Javnu upravu, Zagreb, 2019.

15. Oltmer, Jochen: Migration, Geschichte und Zukunft der Gegenwart, Konrad Theiss Verlag, Darmstadt, 2017.

16. Ortakovski, Vladimir, „Refugee Crisis in Europe and International Law“, u: From an Individual to the European Integration - Discussion on the Future of Europe, Lieber Amicorum in Honour of Silvo Devetak, Maribor, 2019.

17. Radolović, Aldo, Pravo ličnosti kao kategorija građanskog prava, doktorska disertacija obranjena na Pravnom fakultetu Sveučilišta u Zagrebu, Zagreb, 1985.

18. Radolović, Aldo, »Pravo osobnosti u novom Zakonu o obveznim odnosima«, Zbornik Pravnog fakulteta Sveučilišsta u Rijeci, Vol. 27. No. 1., Rijeka, 2006.

19. Speer, Benedikt, »External and Internal Effects of How Austria Has Handlend the Refugee Crisis«, Croatian and Comparative Public Administration, Vol. 18, No 2, 2018.

\section{Pravni propisi:}

20. Ustav Republike Hrvatske, NN 56/90, 135/97, 8/98 - pročišćeni tekst, 113/00, 124/00 - pročišćeni tekst, 28/01, 41/01 - pročišćeni tekst, 55/01, 76/10, 85/10 - pročišćeni tekst, 05/14 - Odluka Ustavnog suda broj: SuP-O-1/2014. od 14. siječnja 2014., kojom je čl. 62. Ustava nadopunjen st. 2.

21. Zakon o statusu prognanika i izbjeglica, NN 96/93, 39/95, 29/99, 128/99, 50/00, $86 / 02,51 / 13,98 / 19$. 
22. Zakonu o azilu, NN 79/07, 88/10, 143/13.

23. Zakon o sportu, NN 71/06, 150/08, 124/10, 124/11, 86/12, 94/13, 85/15, 19/16 ispravak, 98/19.

24. Zakon o obveznim odnosima, NN 35/05, 41/08, 125/11, 78/15, 29/18.

\section{Internetski izvori:}

25. http://www.unhcr.org/protect/PROTECTION/3b66c2aa10.pdf/

26. www.hazu.hr

\section{A SPECIFIC ASPECT OF PERSONALITY RIGHTS IN SPORT RELATED TO THE ABUSE OF REFUGEE AGE}

In this paper, we researched one legal aspect of personality rights related with abuse of age, in which a person in refugee status misrepresents his or her age, which implies an unequal position in favor of the refugee in sports competitions. If accurate information on the age of the athlete competing is not available, it is accepted as the relevant statement by the athlete. The research concluded that positive legal regulation was not appropriate. We have offered the only two possible legally solutions, with the final conclusion that this is a situation where the law is powerless, so other institutional solutions to these doubts need to be found, which should then be incorporated into normative standards in sport.

Key words: public institutions in sport, personality rights, damage, refugees 